\title{
Busca e resgate no mar
}

\author{
Ocean search and rescue
}

\author{
Marcelo Teixeira
}

Teixeira M. Busca e resgate no mar/ Ocean search and rescue. Rev Med (São Paulo). 2012 jan.-mar.;91(1):25-7. RESUMO: Os atendimentos a vítimas que estão no mar principalmente em regiões distantes da costa exigem uma equipe extremamente
especializada e equipada, podendo envolver aeronaves e embarcações. Algumas têm duração de dias. A adaptação do ser humano
para o ambiente aquático é frágil, reduzindo o tempo de sobrevivência, principalmente nos acidentes em que as vítimas não contam com apoio de balsas ou kits de sobrevivência.

DESCRITORES: Salvamento aquático; Trabalho de resgate/recursos humanos; Busca e resgate.

\section{INTRODUÇÃO}

$\Delta s$ atividades no mar, tanto recreativas como Aprofissionais, submetem o ser humano a um ambiente hostil, onde uma simples dor de dente pode ser motivo de operações complexas de resgate.

Por lei internacional, toda embarcação é obrigada a prestar ajuda em situações de emergência, mesmo em tempos de guerra. Entretanto, é rara a presença de estrutura médica nestas, o que impossibilita o atendimento emergencial e a estabilização adequada, principalmente de vítimas moderadas e graves. Por este motivo, as equipes destinadas a operações de SAR (search and rescue) devem ser extremamente especializadas, equipadas adequadamente e estarem à disposição 24 horas por dia 7 dias da semana.

\section{As Ocorrências}

As operações de resgate no mar são desencadeadas pelas mais variáveis causas, desde simples febres a politraumatizados graves. Para exemplificar, imaginem um marinheiro que esteja a 12 dias do porto mais próximo apresentando quadro de cólica renal em um navio que não possui médico a bordo. Um problema simples, que em qualquer cidade seria tratado rapidamente, torna se uma grande operação de resgate onde equipes deverão ser deslocadas por quilômetros mar a dentro.

Abaixo são descritos algumas das ocorrências características com respectivas descrições ou curiosidades.

Coordenador médico do SAMU de Jundiaí, Médico da Equipe de Atendimento Pré-Hospitalar da Formula 1, fórmula Indy e Rally dos Sertões. Capitão Amador pela Marinha do Brasil.

Endereço para correspondência: rua Carmela Nano 181, Jardim Samambaia; Jundiaí, SP. e-mail: Marcelo-zito@ hotmail.com 
Naufrágio: Naufrágio é considerado toda embarcação que perde a capacidade de permanecer na superfície em condições de estabilidade e operacionalidade. Nos casos de naufrágio, o atendimento é caracterizado pela altíssima complexidade, sendo necessária muitas vezes a localização e o resgate de múltiplas vítimas, situação que frequentemente excede a capacidade de atendimento das equipes de resgate locais.

MOB: Ocorrência comum e de altíssima complexidade é o chamado MOB (men over boat) ou popularmente homem ao mar. Possui uma característica peculiar que é a difícil localização da vítima necessitando o empenho de várias equipes e embarcações. Neste caso, a ação imediata de uma equipe bem treinada da própria embarcação de origem da vítima é que faz a grande diferença para a sobrevivência da mesma. O mal tempo (vento, altura das ondas, etc) é um fator que dificulta as operações de resgate $M O B$ e é uma das causas de queda da embarcação.

Acidentes Disbáricos: São patologias ocasionadas na prática do mergulho, onde mergulhadores desenvolvem doença descompressiva, podendo se manifestar desde dores articulares até coma e morte. Estas vítimas necessitam de atendimento especializado muitas vezes com a utilização de câmera hiperbárica.

Emergências Clínicas: Podem ocorrer qualquer emergência clínica em ocupantes de navios, principalmente os de passageiros, porém predominam as infecções, com destaque para as pulmonares. Emergências cardiológicas e desidratação também ocorrem com relativa frequência.

Emergências Odontológicas: Comumente devido à inflamação de canal dentário. Existem vários relatos de marinheiros que extraíram o próprio dente para aliviar a dor intensa.

Emergências Traumáticas: Queimaduras e fraturas são as ocorrências mais comuns. Entre os mecanismos de trauma, destacam-se as quedas, explosões e incêndios.

Traumatismo Ambiental: Hipotermia, intermação, hiponatremia dilucional e exaustão pelo calor. O trabalho nas embarcações comumente é realizado em ambientes fechados e quentes o que propicia a ocorrência de traumatismos ambientais. A hipotermia normalmente é resultado de ocorrências de homem ao mar (MOB).
Emergências Cirúrgicas não Traumáticas: Prevalece a incidência de abdômen agudo inflamatório, abdômen agudo perfurativo e cólica renal.

Características das ocorrências:

> Operações complexas;

> Localização difícil das vítimas;

$>$ Tempo de resgate prolongado; rotativa;

Utilização de aeronave de asa fixa e/ou

$>$ Extração difícil; teorológicas.

Altamente dependente de condições me-

\section{Sobrevivência no Mar - 0 Náufrago}

Em 28 de outubro de 2005, cinco pescadores saíram de San Blas, no México, em um pequeno barco pesqueiro a motor. Foram vistos novamente, somente em 9 de agosto de 2006. Foram resgatados a mais de 4.500 milhas náuticas (8.334 kilômetros) de onde saíram, depois de terem permanecido à deriva na própria embarcação. Dos cinco tripulantes iniciais, três sobreviventes foram resgatados. Segundo seus relatos, haviam sobrevivido 285 dias à deriva no oceano Pacífico, o que representaria um novo recorde de sobrevivência no mar. Haviam sobrevivido se alimentando somente de peixes, tartarugas e aves. A hidratação era obtida pelo consumo de água da chuva e sangue das 108 tartarugas que capturaram.

Este caso extremo de sobrevivência no mar ilustra três dos principais problemas enfrentados pelos náufragos: o clima, a falta de comida e, especialmente, a falta de água potável.

Clima: náufragos estão expostos às condições climáticas variáveis sendo comum a hipotermia mesmo em regiões tropicais. As queimaduras solares também são frequentes.

Falta de Comida: A desnutrição é comum e mesmo que os náufragos consigam pescar, abater tartarugas ou aves estes alimentos são pobres em vitaminas, resultando em hipovitaminose.

Falta de Água Potável: A ingesta de água salgada, mesmo em pequenas doses, reduz substancialmente as chances de sobrevivência da vítima. Isso ocorre devido ao fenômeno de osmose reversa, que desencadeia diarreia e insuficiência renal; aumentando a mortalidade. Os náufragos são obrigados a racionar água potável (preconizado 100ml de água 
por dia por pessoa).

Além dos problemas citados acima, o náufrago deve superar os desafios psicológicos, tais como medo, solidão, tédio, depressão entre outras. Pessoas acostumadas com a vida no mar (marinheiros, pescadores, etc.) possuem maior taxa de sobrevivência devido ao manejo e tolerância psicológica à situação.

\section{Principais Equipamentos de Salvatagem}

Coletes salva-vidas com tarjas refletivas - Obrigatório um para cada passageiro e tripulante da nau.

Balsas, bóias e botes salva-vidas - Existem vários modelos com capacidades distintas, todos devem possuir coloração laranja e faixas refletivas.

Equipamentos Pirotécnicos Sinalizadores Existem 3 tipos:

$\checkmark$ Fumígenos: são equipamentos flutuantes que liberam fumaça laranja, utilizados para localização de pessoas ou embarcações durante o dia, possui duração média de 3 minutos;

$\checkmark$ Facho Manual: Sinalização para salvamento a curta distância, emite intensa luz vermelha com duração de 60 segundos. Utilizado para sinalizar situações de perigo à curta distância, onde se requer luminosidade e duração de sinal. Também pode ser utilizado para iluminar ambientes escuros em emergências;

$\checkmark$ Foguete de Sinalização: Sinaliza situações de perigo a longa distância, tanto de dia quanto de noite. Ejeta um paraquedas luminoso a $300 \mathrm{~m}$ de altitude.

Defletor de Radar - São equipamentos metálicos que facilitam a detecção pelo radar, pois aumentam a deflexão das ondas do mesmo.

AIS (Automatic Identification System) - Equipamento que emite sinais de rádio para outras embarcações informando localização, tipo, velocidade, destino e características da embarcação. Identifica com antecedência por sinal sonoro e luminoso embarcações em rota de colisão, dando tempo para realização de manobras de evasão.

EPIRB (Emergency Position Indicating Radio Beacon) - Equipamento que emite sinais de rádio para embarcações próximas e de satélite para as equipes de salvamento, informando a localização do equipamento (baseado na localização do GPS). Possui ativamento manual ou automático nos casos de naufrágio.

Amplificadores de Ondas de Radar - Equipamentos que ao detectar a presença de ondas de radar ampliam e refletem as mesmas, mandando um sinal característico, facilitando a localização da pessoa ou da embarcação de salvatagem.

\section{REFERÊNCIAS}

Resende CAJ de. Sobrevivência no mar. Rio de Janeiro: Imprensa Naval; 1988.

Barros GLM de. Navegar é fácil. Rio de Janeiro: Catau; 1998.

NAEMT: pré-hospitalar trauma life support. Rio de Janeiro: Elsevier; 2011. 